This is an accepted manuscript of an article published by Elsevier in Emerging Markets Review, available online: https://doi.org/10.1016/j.ememar.2005.11.001

Accepted version downloaded from SOAS Research Online: http://eprints.soas.ac.uk/17715/

\title{
Regulatory changes and market liquidity in Chinese stock markets
}

Lei Gao ${ }^{\mathrm{a}}$ and Gerhard Kling ${ }^{\mathrm{b}}$

${ }^{a}$ Nanjing University of Information Science \& Technology, ${ }^{b}$ University of Southampton THIS IS NOT THE FINAL (POST-REVIEW) VERSION YOU FIND THE FINAL VERSION HERE:

Gao, L. and G. Kling (2006) Regulatory changes and market liquidity in Chinese stock markets, Emerging Markets Review 7(2), 162-175

Our study measures the impact of institutional reforms in China on market liquidity. Using monthly data on turnover ratios, turnover-volatility ratios and stock returns for the Shanghai and Shenzhen Stock Exchange and applying an intervention model, we detect a considerable impact of regulatory changes on liquidity. Motivated by the inventory paradigm and the disposition effect, our empirical model accounts for market returns and macroeconomic shocks. The ban of futures trading reduced market liquidity; however, lower commissions enhanced trading. Market reforms were favourable for the development of financial markets but these effects were not long lasting.

JEL Classification: K22, G28, C22

Key words: Shanghai; Shenzhen; disposition effect; liquidity; regulation 


\section{Introduction}

As China was and to some extent still is a centrally planned economy, the excessive government control is the most conspicuous peculiarity. Yet, since 1990, many regulatory changes have occurred that improved the legal framework and reduced barriers to trade. For instance the stamp tax, which buyer and seller have to pay for every transaction, was reduced several times. Diminishing transaction costs should have stimulated trading. State interventions like the prohibition of 'illegal’ futures trading, however, could have outweighed other improvements. The overall impact of these regulatory changes is unclear and requires clarification to stimulate further beneficial economic reforms.

The purpose of our study is twofold: first, our paper tries to reveal the impact of policy changes on market liquidity on the Shanghai (SSE) and Shenzhen (SZSE) stock exchanges from December 1990 to December 2002; second, we develop an analytical framework for analyzing the influence of regulatory changes on market liquidity. Our model allows anticipation of events, controls for unexpected macroeconomic shocks, accounts for contemporaneous market conditions and models the dynamic response of liquidity. Based on our empirical findings, we formulate policy recommendations to enhance market development not only in China - but also in other emerging markets.

Former research on the interrelation between market reforms and the development of Chinese financial markets concentrated mainly on responses of stock returns triggered by political events. Jin and Tang (2001) claimed that policy factors are the primary reason for market movements in the period from 1992 to 2000 in which 16 huge market fluctuations, whose amplitudes exceeded $20 \%$, occurred. They stressed that $46 \%$ of all market fluctuations were due to regulatory changes. Shi (2001) demonstrated that policy changes were responsible for 30 out of 52 abnormal fluctuations during the period from 1992 to 2000 . Kim and Singal (2000) showed for several emerging markets that abnormal returns on stock markets could be observed about eight months prior to market liberalizations. These studies 
underlined the predominant role of policy changes for share price movements - but they have not discussed whether market reforms have long run effects on market development. An exception is Firth, Fung and Poon's (1998) analysis of the suspension of the Chinese Treasury Bond futures market because they estimated the impact of this specific regulatory change on liquidity and not only on stock returns - but their study was focused on this single event. A central aspect of market development is reaching a high level of market liquidity, which is a prerequisite for efficient markets, as transactions convey private information and increase the information content of share prices. ${ }^{1}$ Several papers emphasized that well-operating financial markets are a catalyst for economic development (see Levine and Zervos, 1998). In particular, higher market liquidity is positively related to economic growth, progress in productivity, and expansion of capital accumulation. Hence, market reforms should enhance market liquidity to facilitate investment and guarantee long run economic growth.

Our paper is organized as follows. The literature review highlights the role of the state in Chinese stock markets and theoretical considerations concerning the relation between returns and liquidity. Part three describes the dataset and discusses different measures of market liquidity. Section four derives the empirical model followed by our findings. Finally, the conclusion tries to identify policy recommendations based on our empirical results and provides advice for practitioners, who could benefit from higher liquidity.

\section{Literature review}

\subsection{The role of the state in Chinese stock markets}

When SSE and SZSE were launched in the early 1990s, the State Council of China invented three different share categories in order to prevent the mass privatization of state-owned enterprises (SOE). This market segmentation has considerable impact on market liquidity, as only a small fraction of all shares is tradable. In particular, a SOE had to issue three different

\footnotetext{
${ }^{1}$ This argumentation follows the seminal papers of Kyle (1985) and O’Hara (2003).
} 
types of shares, when it restructured into a publicly listed company. About a third of a company's equity are state shares hold by the bureaus of the Ministry of Finance and ultimately owned by the State Council. State shares cannot be traded, and their transfer is subject to multiple administrative approvals (see Green, 2003). Another third of a company’s equity is made up of legal person shares. They are allocated to other SOEs that contribute capital to restructure companies. They cannot be traded on stock exchanges, although they can be exchanged (see Green, 2003). The final third of a company's equity are individual person shares that can be traded by private investors and institutions. Consequently, the free float (tradable shares) accounts for less than 25\% - but it increases steadily. Fig. 1 plots the free float relative to the total market capitalization.

Due to the socialist ideological heritage, the financial system is regarded as a passive instrument to serve the national economy in China (see Heilmann 2002). Hence, Chinese authorities from the outset strictly regulate financial markets. There are many regulatory authorities, such as the Central Financial Work Committee that sets the principles and major objectives of stock market regulation. The China Securities Regulatory Commission (CSRC) is responsible for the executive work under the political supervision of the Central Financial Work Committee, the Central Bank of China, the Communist Party’s Central Committee and the Central Government of China.

\subsection{Relation between returns and liquidity}

There is a broad literature on the interrelation between expected stock returns and liquidity of individual stocks (see Amihud and Mendelson, 1986, Jacoby, Fowler, and Gottesman, 2000, Brennan and Subrahmanyam, 1996). They argued that rational investors require a compensation for holding assets with low liquidity due to liquidity risk. This strand of the literature focuses on cross-sectional differences in liquidity and risk premiums. As our study 
analyzes changes of market liquidity in one country over time, we cannot work with these theoretical considerations.

The time-series behavior of market liquidity has not been extensively studied. An exception is the seminal paper of Chordia, Roll, and Subrahmanyam (2001) that focused on NYSE data from 1988 to 1998. They calculated on a daily basis several aggregated market liquidity measures and explored their time series characteristics. To identify explanatory variables for market liquidity, they followed the inventory (see Demsetz, 1968, Stoll, 1978, Ho and Stoll, 1981) and informed trading (see Kyle, 1985, Admati and Pfeiderer, 1988) paradigms. The inventory paradigm stresses that liquidity depends on factors that affect the risk of holding inventory; thus, extreme events that provoke order imbalances and market conditions, namely market returns and volatility, are relevant factors.

Informationally motivated trading affects liquidity; hence, the release of news concerning macroeconomic conditions should be relevant for liquidity. Jun, Marathe, and Shawky (2003) emphasized that macroeconomic variables, political conditions, and the legal framework determine market liquidity. Consequently, we control for unexpected macroeconomic shocks.

Chordia, Roll, and Subrahmanyam (2001) found seasonal patterns in market liquidity using daily data, and Draper and Paudyal (1997) detected seasonality in monthly market liquidity. As we work with monthly data, seasonal patterns like the January effect (see Jegadeesh and Titman, 1993) might play a role. The January effect refers to tax-motivated trading, namely selling stocks in December in order to reduce taxable income by realizing losses and buying stocks back in January. Due to the fact that capital gains are free of any taxes in China, the January effect is not observable (see Gao and Kling, 2005).

In the time dimension, Chordia, Roll, and Subrahmanyam (2001) showed that market returns positively affect market liquidity, which differs from cross-sectional studies. Hence, based on the inventory paradigm, we should expect a positive correlation between market 
returns and liquidity, as positive returns reduce inventory risk. However, behavioral finance offers an additional explanation for a positive effect of market returns on liquidity, namely the disposition effect. Shefrin and Statman (1985) coined the term disposition effect that describes market agents' inclination to sell winners too early and ride losers too long. Lakonishok and Smidt (1986) reported that abnormal trading volume is higher for winners; thus, their finding suggests that investors prefer selling winners. When market returns are positive, more stocks belong to the winner category. On an individual basis, investors are more willing to sell winners than losers; hence, when the market goes up, more transactions occur.

\section{The data}

Datastream comprises monthly stock prices of all `A shares' listed on the SSE and SZSE from December 1990 to December 2002. Turnover ratios are calculated based on the data provided by the China Securities regulatory Commission (CSRC), namely monthly trading volume and monthly market capitalization (free float). ${ }^{2}$ Daily newspapers and other publicly accessible sources (like www.csrc.gov.cn) broadcast regulatory changes. Based on newspaper archives, we compiled the chronology of regulatory changes summarized in Table 1.

Besides turnover ratios as measure of liquidity, Jun, Marathe, and Shawky (2003) recommend to calculate turnover-volatility ratios. Chinese stock markets are characterized by high volatility due to speculation; hence, using turnover-volatility ratios can control for these peaks in market fluctuations that do not contribute to long-term financial development. ${ }^{3}$ Bekaert, Harvey, and Lundblad (2005) used the proportion of zero daily firm returns as indicator of liquidity. The advantage of this measure is that information on firm specific

\footnotetext{
${ }^{2}$ Data are available online www.csrc.gov.cn.

${ }^{3}$ To calculate turnover-volatility ratios, we predict conditional volatilities applying GARCH(1,1) models to monthly stock returns (see Bollerslev, 1986). Then, turnover ratios are divided by conditional volatilities.
} 
trading volume is not required. A practical problem of this measure is that daily stock returns for every listed firm are not available for the whole period from 1990 to 2002. Besides macro measures of liquidity, there exist several possibilities to observe liquidity on the micro level using stock specific data like bid-ask spreads (see Brockman and Chung, 2003). Unfortunately, micro level information is not available for the whole period under investigation. Moreover, data on firm specific trading volume provided by Datastream are not reliable for China; hence, indirect measures of liquidity that are based on regressing returns on volume are not feasible for our analysis. To illustrate the development of liquidity on both exchanges, Fig. 2 plots turnover ratios and turnover-volatility ratios. As trading mechanisms are almost identical and both exchanges are exposed to the same set of political and macroeconomic factors, one can observe a very similar pattern of market liquidity.

As market liquidity could be affected by political as well as macroeconomic circumstances, we have to control for macroeconomic shocks. The IMF provides macroeconomic data for China; however, some series are not available for the whole investigation period. Expected macroeconomic changes should be reflected by stock market returns - but sudden unexpected shocks might have an impact. In line with multi-factor models and more precisely Chen, Roll, and Ross (1986), who favored predefining a set of macroeconomic variables compared to factor analysis (Gehr, 1978, Roll and Ross, 1980), we use four relevant macroeconomic variables: manufacturing production, lending rates as a proxy for short run interest rates, exchange rates, and consumer prices. ${ }^{4}$ All variables are available on a monthly basis since December 1990 - except manufacturing production, which consists of quarterly information. To determine unexpected components of these macroeconomic variables, we follow Chen and Jordan (1993). Consequently, exploiting serial dependencies by autoregressive processes, macroeconomic shocks can be derived.

\footnotetext{
${ }^{4}$ Exchange rates are more or less stable from 1990 to 2002, albeit a pronounced depreciation occurred in April 1994 accompanied by the introduction of the Forex trading system.
} 


\section{The empirical model}

\subsection{Descriptive statistics and unit-root tests}

Table 2 summarizes descriptive statistics of market returns, turnover ratios, turnover-volatility ratios, and unexpected macroeconomic shocks. In addition, column six shows test statistic of unit root tests to reveal whether the respective time series is stationary. All variables are stationary, as modified Dickey-Fuller tests reject their null hypotheses. ${ }^{5}$ Consequently, we can include market returns and our proxies for market liquidity as endogenous time series into a VAR framework to test for causalities in both directions. Average market returns are higher on the SSE compared to the SZSE, but volatility of market returns is higher on the SSE. On average, the SEE exhibits higher turnover ratios and turnover-volatility ratios; however, market liquidity fluctuates more on the SEE than on the SZSE.

\subsection{VAR approach and Granger causality tests}

To analyze the direction of causality between market returns and liquidity, we build up a simple VAR model and test for Granger causality. Market returns $r_{t}$ and market liquidity $\tau_{t}$ are both endogenous time series, which depend on their former values expressed by the sum of lagged returns $r_{t-j}$ and market liquidity $\tau_{t-j}$. The vector c consists of constant terms for both equations, and the vector $\mathbf{e}_{\mathbf{t}}$ contains error terms for both equations at time t.

$$
\left(\begin{array}{l}
r_{t} \\
\tau_{t}
\end{array}\right)=\mathbf{c}+\sum_{j=1}^{p} \Phi_{j}\left(\begin{array}{c}
r_{t-j} \\
\tau_{t-j}
\end{array}\right)+\mathbf{e}_{\mathbf{t}}
$$

To determine the optimal lag length p of the VAR model, the Akaike (AIC), Hannan-Quinn (HQIC), and the Bayesian information (BIC) criteria are calculated. For both exchanges and

\footnotetext{
${ }^{5}$ Elliot, Rothenberg, and Stock (1996) modified the standard ADF procedure by applying a GLS approach to control for serial correlation and heteroscedasticity in the data. Yet standard ADF tests point in the same direction. Nevertheless, the GLS procedure increases the power of the ADF tests especially for smaller samples.
} 
both measures of liquidity, all criteria favor one lag. Table 3 contains the outcomes of Granger causality tests, which are based on the basic VAR model (1) and two extended versions. Based on Table 1, we insert dummy variables for exogenous regulatory changes to account for structural shifts in constant terms. This enables to control for political events. Furthermore, the third specification of VAR models accounts for unexpected macroeconomic shocks. Based on causality tests, one can conclude that returns Granger cause turnover ratios - but not vice versa. Consequently, we confirm the findings of Jun, Marathe, and Shawky (2003). ${ }^{6}$ Motivated by Jun, Marathe, and Shawky's (2003) and our finding that returns Granger cause liquidity, we can apply a transfer function approach to model turnover ratios, as returns can be regarded as exogenous.

Granger causality tests for VAR model with turnover-volatility ratios underline that market returns do not influence turnover-volatility ratios significantly. This finding is due to the fact that by calculating turnover-volatility ratios the market condition, namely market volatility, is already included in this proxy of market liquidity.

\subsection{ARIMA specification of turnover ratios}

As returns Granger cause turnover ratios and not vice versa, we simplify our VAR approach in the sense that we impose restrictions on the coefficient matrix $\Phi$; thus, we end up with a simple AR(p) specification and add potential moving average components. In line with Jun, Marathe, and Shawky (2003), we account for a linear time trend $t$ in market liquidity. The series of market returns $r_{t}$ can be regarded as exogenous and might influence market liquidity $\tau_{t}$. Consequently, one can call this model a transfer function approach in which the relation

\footnotetext{
${ }^{6}$ They start with an extended CAPM that accounts for aggregated liquidity; hence, market returns are their dependent variable. They conduct Granger causality tests and underline that returns influence liquidity and not vice versa. We confirm this finding - but we start with a VAR approach; thus, we do not predefine that returns or liquidity are exogenous. Consequently, our approach differs - but the conclusion is exactly the same.
} 
between market liquidity and returns is transferred by the arbitrary polynomial in the lag operator L denoted $\chi(L) .{ }^{7}$ Previous market liquidity $\tau_{t-j}$ accounts for the autoregressive AR(p) nature of liquidity, and former values of the error term $u_{t-j}$ represent the moving average component MA(q).

$$
\tau_{t}=c+b \cdot t+\sum_{j=1}^{p} a_{j} \tau_{t-j}+\sum_{j=1}^{q} m_{j} u_{t-j}+\gamma(L) r_{t}+u_{t}
$$

To determine the lag structure of the lag operator $\gamma(L)$, cross-correlograms between market returns and liquidity are considered. For both exchanges, current market returns and the first lag affect current turnover ratios. This specification is in line with Chordia, Roll and Subrahmanyam (2001), who control for current market conditions by inserting volatility and returns. As we use turnover-volatility ratios, volatility is already reflected in our measurement of market liquidity; hence, we do not have to add volatility as explanatory variable. ${ }^{8}$

Besides finding an optimal transfer function, the ARMA specification of our model should be considered by applying standard Box-Jenkings procedures and comparing information criteria for different specifications. Based on the respective autocorrelation and partial autocorrelation functions, turnover ratios of the SSE and SZSE can be modeled as ARMA $(1,2)$ processes, whereas ARMA $(1,1)$ processes yield the best model fit for turnovervolatility ratios for both stock markets.

\subsection{Intervention model}

\footnotetext{
${ }^{7}$ Enders (2004) discusses simpler transfer function models and is a useful source for understanding this approach.

${ }^{8}$ Compared to Bekaert, Harvey and Lumsdaine’s (2002) endogenous break model, our model also allows endogenous breaks in that an arbitrary lead/lag operator is inserted for every policy change. Based on crosscorrelations, we determine endogenously whether policy changes are anticipated. In contrast to Bekaert, Harvey and Lumsdaine (2002), our model allows long-lasting effects, and we model the dynamic response of liquidity triggered by policy changes.
} 
We extend our transfer function approach by inserting the influence of regulatory changes; consequently, the model has now the following shape.

$$
\tau_{t}=c+b \cdot t+\sum_{j=1}^{p} a_{j} \tau_{t-j}+\sum_{j=1}^{q} m_{j} u_{t-j}+\gamma(L) r_{t}+\sum_{k=1}^{K} \delta_{k}(L) d_{k}+u_{t}
$$

The $K$ regulatory changes are modeled by dummy variables $d_{k}(\mathrm{k}=1, \ldots, \mathrm{K})$ that take the value one when the respective policy change occurred as listed in Table 1. The lag operator $\delta_{k}(L)$ allows an arbitrary lag or lead structure for every policy change. To determine the lag or lead structure of the market reaction triggered by regulatory changes, we derive crosscorrelograms for market liquidity and the respective regulatory change. Hence, the model allows that market liquidity increase in anticipation of liberalizations. Yet we cannot find evidence concerning anticipation, as only the cross-correlation coefficient at lag zero (immediate reaction) is significantly different from zero and reaches on average 0.174 for the SSE and 0.213 for the SZSE.

To account for unexpected macroeconomic shocks, which can be regarded as exogenous, ${ }^{9}$ we extent our intervention model (3) by inserting unexpected changes in manufacturing production $\left(M P_{\mathrm{t}}\right)$, lending rates $\left(L R_{t}\right)$, consumer price changes $\left(C P_{t}\right)$, and exchange rate changes $\left(E R_{t}\right){ }^{10}$

$$
\begin{gathered}
\tau_{t}=c+b \cdot t+\sum_{j=1}^{p} a_{j} \tau_{t-j}+\sum_{j=1}^{q} m_{j} u_{t-j}+\gamma(L) r_{t}+\sum_{k=1}^{K} \delta_{k}(L) d_{k}+ \\
\lambda_{1} M P_{t}+\lambda_{2} L R_{t}+\lambda_{3} C P_{t}+\lambda_{4} E R_{t}+u_{t}
\end{gathered}
$$

Table 4 reports the outcomes of model (3) and model (4) for turnover ratios and turnovervolatility ratios. Current and previous market returns have a positive influence on turnover ratios; this is in line with former findings of Jun, Marathe, and Shawky's (2003) for several

\footnotetext{
${ }^{9}$ Granger causality tests show that unexpected macroeconomic shocks are not Granger caused by market returns or market liquidity.

${ }^{10}$ The highest correlation coefficient among macroeconomic shocks is 0.2487 (between exchange rate and production shocks); therefore, multicollinearity is not a problem for our model (4).
} 
emerging markets and of Chordia, Roll, and Subrahmanyam (2001) for the NYSE. Whether the positive impact of market returns on liquidity is due to the inventory paradigm or the disposition effect is difficult to determine. Nevertheless, controlling for market returns seems to be warranted. When using turnover-volatility ratios as dependent variable, market returns have still a positive influence on liquidity, but coefficients are not significant for the SSE (pvalue is equal to 0.11 ). As sudden increases in share prices like on $21^{\text {st }}$ March 1992 (see $t=18$ in Table 1 and 4) are accompanied by a peak in conditional volatility, turnover-volatility ratios fall after the announcement of the "free stock price through free trading" rule. This explains why coefficients for the regulatory change in $\mathrm{t}=18$ are negative and significant for the SZSE. Besides this deviation, results for turnover ratios and turnover-volatility ratios are rather similar. In all cases, linear time trends $t$ are not relevant; hence, liquidity does not steadily improve over time, which is an important finding. Macroeconomic factors are not essential for explaining market liquidity in China; only an unexpected increase in inflation rates triggers lower turnover-volatility ratios on the SZSE. When we focus on economically and statistically important regulatory changes that are confirmed by all models, two negative events ( $t=43,55)$ and eight positive reactions $(t=33,40,54,71,72,73,78,111)$ can be revealed. The prohibition of illegal futures trading $(\mathrm{t}=43)$ was counterproductive for market development and is one reason why derivative markets are still underdeveloped in China. Yet the second restriction concerning futures trading, namely with Treasury bonds as underlying, on $17^{\text {th }}$ May $1995(t=54)$ had a positive influence on market liquidity. This second policy change tried to restrict excessive speculation in the Chinese Treasury Bond market, which attracted a huge amount of hot money. Accordingly, we confirm the findings of Fung, Firth, and Poon (1998), who analyzed the impact of the suspension of the Chinese Treasury Bond futures market on market returns and liquidity. They showed that liquidity increases on both Chinese exchanges and explained this finding by spillover effects between the Treasury bond futures market and Chinese stock exchanges. The ban for commercial banks to enter stock and 
trust businesses on $20^{\text {th }}$ June $1995(t=55)$ reduced the chance regarding the development of more mature institutional investors and led to a reduction in liquidity. The introduction of a common order-driven market $(\mathrm{t}=33$ ) on the SEE caused higher liquidity on both exchanges, as this announcement was seen as a commitment for introducing more professional trading mechanisms. From $3^{\text {rd }}$ October 1996 to $21^{\text {st }}$ May $1997(t=71,72,73,78)$, a series of four regulatory changes occurred, which increased market liquidity. As these regulatory changes are timely very close, our intervention model cannot precisely distinguish among these policy changes because impacts overlap. Due to the autoregressive nature of turnover and turnovervolatility ratios, about $70 \%$ of the impact of a policy change is still observable in the following months. Hence, the pronounced increase caused by the reduction of commissions for stock and fund transactions outweighed the negative impact of the prohibition of using bank loans for purchasing stocks. The larger range of price fluctuations announced on $16^{\text {th }}$ December 1996 had a considerable positive impact on liquidity. Yet, the positive reaction caused by the ban of SOE and listed companies to conduct stock trading requires explanations. SOEs purchase usually shares of other SOEs for the sake of deterring takeovers. Shares hold by SOEs cannot be regarded as free-float (see Fig.1) and hence banning trades of SOEs should enhance market liquidity. Since $14^{\text {th }}$ February $2002(t=111)$, stock mortgage could be accepted by security companies, which stimulated trading.

Based on the results summarized in Table 4 and the autoregressive nature of turnover ratios, Fig. 3 depicts the dynamic response in turnover ratios due to institutional reforms for both markets over the whole investigation period. Generally, both stock exchanges exhibit similar dynamic responses, and the regulatory impact lasts for several months.

\section{Conclusion}

Bekaert, Harvey and Lumsdaine (2002) found that financial markets tend to be more liquid after regulatory changes that enhance market integration. Our results suggest that reforms can 
increase liquidity - but we cannot find a steady improvement of market liquidity over time. Policy changes announced in the daily newspaper trigger pronounced reactions in market liquidity regardless whether turnover or turnover-volatility ratios measure liquidity. Macroeconomic shocks hardly affect market liquidity.

Applying our model to the SEE and SZSE allows detecting differences regarding their ability to tend back to equilibrium after an exogenous regulatory change. ${ }^{11}$ Accordingly, we can state that turnover ratios of the SSE reach their former values with higher velocity than turnover ratios of the SZSE. Yet when using turnover-volatility ratios this alleged advantage of the SSE vanishes, as the autoregressive nature is similar on both exchanges. Based on these findings, we can state that the SSE cannot cope better with political events than the SZSE.

Which policy recommendations should be drawn based on our empirical findings? The public release of information regarding an imminent regime shift possesses a strong influence on market liquidity. We can state that regulatory changes do not influence market liquidity in the long run. Regulatory changes alone are not a guarantee for higher market liquidity in the long run and hence have to be associated with advanced market integration (see Bekaert, Harvey and Lumsdaine (2002).

Practitioners should be aware of the fact that regulatory changes cause a pronounced increase in liquidity without increasing volatility; hence, trading large quantities becomes easier on the notoriously thin Chinese stock market after announced policy changes.

It is noteworthy that we achieved these results after controlling for stock returns, anticipation of regulatory changes, macroeconomic shocks, and the autoregressive nature of turnover and turnover-volatility ratios. Our methodology could be also applied to other financial markets and might stimulate additional research on the interrelation between legal frameworks and financial markets.

\footnotetext{
${ }^{11}$ Note that we use the term `equilibrium’ in an econometric sense.
} 


\section{Reference}

Admati, A.R. and P. Pfeiderer, 1988, A theory of intraday patterns: Volume and price variability, Review of Financial Studies 1, 3-40.

Amihud, Y. and H. Mendelson, 1986, Asset pricing and the bid-ask spread, Journal of Financial Economics 17, 223-249.

Bekaert, G., Harvey, C.R. and R.L. Lumsdaine, 2002, Dating the integration of world equity markets, Journal of Financial Economics 65, 203-247.

Bekaert, G., Harvey, C.R. and c. Lundblad, 2005, Liquidity and expected returns: Lessons from emerging markets, NBER Working Paper 11413.

Bollerslev, T., 1986, Generalized autoregressive conditional heteroscedasticity, Journal of Econometrics 31, 307-327.

Brennan, M.J. and A. Subrahmanyam, 1996, Market microstructure and asset pricing: On the compensation for illiquidity in stock returns. Journal of Financial Economics 41, 441464.

Brockman, P. and D.Y. Chung, 2003, Investor protection and firm liquidity, Journal of Finance 58, 921- 937.

Chen, S.-J. and B.D. Jordan, 1993, Some empirical tests in the arbitrage pricing theory: Macrovariables vs. derived factors, Journal of Banking and Finance 17, 65-89.

Chen, N.F., Roll, R. and S.A. Ross, 1986, Economic forces and the stock market, Journal of Business 59, 383-403.

Chordia, T., Roll, R. and A. Subrahmanyam, 2001, Market liquidity and trading activity, Journal of Finance 56, 501-530.

Demsetz, H., 1968, The cost of transacting, Quarterly Journal of Economics 82, 33-53.

Draper, P. and K. Paudyal, 1997, Microstructure and seasonality in the UK equity market, Journal of Business Finance and Accounting 24, 1177-1204. 
Elliot, G., Rothenberg, T. and J.H. Stock, 1996, Efficient tests for an autoregressive unit root, Econometrica 64, 813-836.

Enders, W., 2004, Applied Econometric time series, John Wiley \& Sons.

Firth, M., Fung, H.G. and W.P.H. Poon, 1998, The spillover effects of the trading suspension of the Treasury Bond futures market in China, Journal of International Financial Markets, Institutions \& Money 8, 205-218.

Gao, L. and G. Kling, 2005, Calendar effects in Chinese stock market, Annals of Economics and Finance 6, 75-88.

Gehr, A., Jr., 1978, Some tests of the arbitrage pricing theory, Journal of the Midwest Finance Association, 91-105.

Green, S., 2003, China’s stock market: eight myths and some reasons to be optimistic, Royal Institute of International Affairs, Cambridge University.

Heilmann, S., 2002, The Chinese stock market: Pitfalls of a policy-driven market, China analysis 15 .

Ho, T. and H.R. Stoll, 1981, Optimal dealer pricing under transactions and return uncertainty, Journal of Financial Economics 9, 9, 47-73.

Jacoby, G., Fowler, D.J. and A.A. Gottesman, 2000, The capital asset pricing model and the liquidity effect: A theoretical approach, Journal of Financial Markets 3, 69-81.

Jegadeesh, N. and S. Titman, 1993, Returns to Buying Winners and Selling Losers: Implications for Stock Market Efficiency, Journal of Finance 48, 65-91.

Jin, X.B. and L.M. Tang, 2001, On the game between government policy and stock investors, Working Paper of Haitong Security Company.

Jun, S.G., Marathe, A. and H.A. Shawky, 2003, Liquidity and stock returns in emerging equity markets, Emerging Markets Review 4, 1-24.

Kim, E.H. and V. Singal, 2000, Stock market openings: Expectations of emerging economies, Journal of Business 73, 25-66. 
Kyle, A. S., 1985, Continuous auctions and insider trading, Econometrica 53, 1315-1335.

Lakonishok, J.A. and S. Smidt, 1986, Volume for winners and losers: Taxation and other motives for stock trading, Journal of Finance 41, 951-974.

Levine, R. and S. Zervos, 1998, Stock market, banks and economic growth, American Economic Review 88, 537-558.

O’Hara, M., 2003, Presidential address: Liquidity and price discovery, Journal of Finance 58, $1335-1354$.

Roll, R. and S.A. Ross, 1980, An empirical investigation of the arbitrage pricing theory, Journal of Finance 35, 1073- 1103.

Shefrin, H. and M. Statman, 1985, The disposition to sell winners too early and ride losers too long: Theory and evidence, Journal of Finance 40, 777-790.

Shi, D.H, 2001, The theory and practice of the micro-behavior of the Chinese stock market, Shanghai Far East Publishing House, Shanghai.

Stoll, H.R., 1978, The supply of dealer services in securities markets, Journal of Finance 33, 1133-1151. 
Table 1: Important regulatory changes from December 1990 to December 2002

\begin{tabular}{|c|c|c|}
\hline t & Date & Regulatory changes \\
\hline 5 & 26.04 .1991 & The limit of daily price fluctuations increased from $0.5 \%$ to $1 \%$ \\
\hline 7 & 03.06.1991 & The stamp tax decreased from $0.6 \%$ to $0.3 \%$ \\
\hline 18 & 21.05.1992 & $\begin{array}{l}\text { Free stock price through free trading - less control of price formation } \\
\text { (The Shanghai Index increased from } 617 \text { point to } 1266 \text { point at that day) }\end{array}$ \\
\hline 23 & 26.10.1992 & China Securities Regulatory Commission opened on 25.10.1992 \\
\hline 33 & 06.08 .1993 & $\begin{array}{l}\text { A common order-driven market for 'A shares' on Shanghai Stock Exchange } \\
\text { was introduced } \\
\text { (Buy and sell orders compete for the best price. Throughout the trading } \\
\text { session, customer orders are continuously matched at a price satisfying both } \\
\text { parties, according to price and time priorities.) }\end{array}$ \\
\hline 40 & 14.03.1994 & $\begin{array}{l}\text { Announcement of 'Four No' rule on } 12.03 .1994 \\
\text { (On 12.03.1994, the Chairman of China Securities Regulatory Commission } \\
\text { (CSRC) announced that RMB } 5.5 \text { billion new shares are not allowed to be } \\
\text { traded on stock exchanges within half a year; the transaction tax for stocks } \\
\text { would not be levied in 1994; the state share and corporate share would not } \\
\text { be listed in 1994; the control on listed company's stock allotment right } \\
\text { would not be relaxed.) }\end{array}$ \\
\hline 43 & 15.06.1994 & Prohibition of illegal futures trading \\
\hline 45 & 01.08.1994 & $\begin{array}{l}\text { Three bail-out measures were announced by the China Securities Regulatory } \\
\text { Commission (CSRC) on } 30.07 .1994 \\
\text { (From } 1993 \text { to } 1994 \text { the Shanghai Stock Market Index decreased from } 1500 \\
\text { point to } 325 \text { point and the trading volume was extremely small. On } \\
\text { 30.07.1994, the CSRC announced three bail-out measures: stopping issuing } \\
\text { new stocks, allowing security companies to finance and establishing joint- } \\
\text { funds with foreign financial institutions. On } 01.08 .1994 \text {, the Shanghai Stock } \\
\text { Market Index increased by } 33.2 \% \text {, and some stocks appreciated nearly } \\
100 \% \text {. In the next month, the index increased from above } 300 \text { points to } \\
\text { above } 1000 \text { points.) } \\
\text { Initiate } T+1 \text { trading procedure }\end{array}$ \\
\hline 50 & 03.01.1995 & $\begin{array}{l}\text { (Stocks bought today cannot be sold until tomorrow. This reduces intra-day } \\
\text { trading.) }\end{array}$ \\
\hline 54 & 17.05.1995 & $\begin{array}{l}\text { Stop of futures trading on Treasury Bonds } \\
\text { (In early 1995, the overdue speculation in the Chinese Treasury Bonds } \\
\text { Futures market attracted too much hot money from the Chinese stock } \\
\text { market that exhibited a decline in daily trading volume to } 20 \text { million shares. } \\
\text { On } 17.05 .1995 \text {, the CSRC banned the trading of futures on Treasury Bonds. } \\
\text { On that day, the Chinese stock market index increased by } 30.99 \% \text { and the } \\
\text { trading volume increased to RMB } 8.493 \text { billion. Within three days, the } \\
\text { index increased } 60 \% \text {.) }\end{array}$ \\
\hline 55 & 20.06.1995 & Ban for commercial banks to enter stock and trust businesses \\
\hline 56 & 03.07.1995 & Increase of the lending interest rate \\
\hline 71 & 03.10 .1996 & Decrease in commissions for stock and fund transactions \\
\hline 72 & 14.11 & $\begin{array}{l}\text { The Central Bank of China prohibits that bank loans can be used to invest in } \\
\text { stocks }\end{array}$ \\
\hline 73 & 16.12.1996 & The limit of daily price fluctuation increased to $10 \%$ \\
\hline 78 & 21.05.1997 & Ban for SOE and listed companies to conduct stock trading. \\
\hline
\end{tabular}


79 06.06.1997 The Central Bank of China prohibits that assets owned or controlled by banks can be used to purchase stocks.

$91 \quad 12.06 .1998$ The stamp tax decreases from $0.5 \%$ to $0.4 \%$

102 19.05.1999 The China Securities Regulatory Commission (CSRC) announced several regulatory changes

(From May 1997 to May 1999, the Chinese stock market was a bear market; hence, trading volume was very small. On 19.05.1999, after a talk with the heads of security companies and the government, the China Securities Regulatory Commission announced several regulatory changes: reconstructing the stock issue mechanism, allowing assets of insurance companies to enter the stock market, improving the way of financing security companies (investment banks), allowing some security companies to issue bonds, enlarging the market size of investment funds, strengthening 'B share' market and allowing some `B share' or 'H share' companies to repurchase their stocks. The market rose immediately.)

106 08.09.1999 China Securities Regulatory Commission allowed SOEs, the statecontrolled enterprises and the listed companies to issue shares and trade stocks.

(On 08.09.1999, China Securities Regulatory Commission allowed the SOEs, the state-controlled enterprises and the listed companies to issue shares and trade stocks at the first and second market. Yet the time span of round trips of the same stock must be longer than six months. On the ensuing day 09.09.1999, the Shanghai Exchange Index increased by 6.59\%; however, this impact was not long lasting.)

111 14.02.2000 Initiation of the rule regarding stock mortgage of security companies

Stipulation concerning security companies' senior mangers' interview

122 15.01.2001 responsibilities

131 23.10.2000 China Securities Regulatory Commission announced to provisionally stop selling state owned shares

(On 23.10.2000, China Securities Regulatory Commission announced to provisionally stop selling state owned shared as IPO or APO. When the news arrived at the Chinese stock market, it increased nearly $10 \%$ immediately.)

132 16.11.2001 The stamp tax decreased to $0.2 \%$.

139 24.06.2002 China Central Government announced to stop selling state owned shares (At 19 o'clock on 24.06.2002, China Central Television broadcasted the announcement that the China Central Government abolished to sell state owned shares. On the following day, the market index increased nearly by $10 \%$ and the trading volume of RMB 89.8 billion reached an all time high.)

Note: The column ' $t$ ' indicates the respective month of the regulatory change during the 133

months from December 1990 to December 2002. We provide additional explanations in parentheses. 


\section{Table 2: Descriptive statistics and unit root tests}

This table summarizes descriptive statistics of market returns, measures of market liquidity, and unexpected macroeconomic shocks. To test for stationarity, we apply a modified DickeyFuller test and select the optimal lag by the Schwarz (SIC) criterion. *, **, and *** indicate significance on the 10,5 , and $1 \%$ level of significance.

\begin{tabular}{|c|c|c|c|c|c|}
\hline & Mean & $\begin{array}{l}\text { Standard } \\
\text { deviation }\end{array}$ & Minimum & Maximum & $\begin{array}{r}\text { ADF tes } \\
\text { statistic }\end{array}$ \\
\hline $\begin{array}{l}\text { Market return } r_{t} \\
\text { (SSE) in \% }\end{array}$ & 1.9372 & 17.1271 & -37.3283 & 101.9663 & $-7.983^{* * *}$ \\
\hline $\begin{array}{l}\text { Market return } r_{t} \\
\text { (SZSE) in \% }\end{array}$ & 1.0378 & 13.8708 & -28.9747 & 62.5077 & $-7.378^{* * *}$ \\
\hline $\begin{array}{l}\text { Turnover ratio } \tau_{t} \\
\text { (SSE) in } \%\end{array}$ & 2.5693 & 2.1481 & 0.0337 & 12.1507 & $-3.805^{* * *}$ \\
\hline $\begin{array}{l}\text { Turnover ratio } \tau_{t} \\
\text { (SZSE) in \% }\end{array}$ & 2.1194 & 1.8831 & 0.1871 & 9.3715 & $-3.852^{* * *}$ \\
\hline $\begin{array}{l}\text { Turnover-volatility } \\
\text { ratio } \tau_{t}(\mathrm{SSE})\end{array}$ & 0.1874 & 0.1343 & 0.0018 & 0.7497 & $-3.706^{* * *}$ \\
\hline $\begin{array}{l}\text { Turnover-volatility } \\
\text { ratio } \tau_{t}(\mathrm{SZSE})\end{array}$ & 0.1492 & 0.1066 & 0.0124 & 0.6688 & $-3.782^{* * *}$ \\
\hline $\begin{array}{l}\text { Unexpected change } \\
\text { in production } M P_{t}\end{array}$ & 0.0284 & 2.5773 & -9.5397 & 16.3383 & $-4.117^{* * *}$ \\
\hline $\begin{array}{l}\text { Unexpected lending } \\
\text { rate } L R_{t}\end{array}$ & -0.0036 & 0.2738 & -0.7724 & 1.3320 & $-4.922^{* * *}$ \\
\hline $\begin{array}{l}\text { Unexpected inflation } \\
\qquad C P_{t}\end{array}$ & -0.0182 & 0.6735 & -2.2682 & 3.5665 & $-6.633^{* * *}$ \\
\hline $\begin{array}{l}\text { Unexpected changes } \\
\text { in exchange rate } E R_{t}\end{array}$ & 0.000 & 0.0091 & -0.0591 & 0.0277 & $-10.560^{* * *}$ \\
\hline
\end{tabular}


Table 3: Granger causality tests for returns and liquidity measures

We run VAR model with one lag and test for Granger causality between returns and market liquidity. The first three models use turnover ratios as measure of liquidity, while model (4), (5), and (6) use turnover-volatility ratios. Model (1) and (4) are VAR models with returns and liquidity as endogenous variables. Model (2) and (5) account for exogenous regulatory changes. Model (3) and (6) include policy changes and unexpected macroeconomic shocks. P-values are set in parentheses.

\begin{tabular}{|c|c|c|}
\hline \multirow[t]{2}{*}{ Null hypotheses } & \multicolumn{2}{|c|}{ " Granger causality tests - Wald test statistics } \\
\hline & $\begin{array}{c}\text { Shanghai Stock Exchange } \\
\text { (SSE) }\end{array}$ & $\begin{array}{c}\text { Shenzhen Stock Exchange } \\
\text { (SZSE) }\end{array}$ \\
\hline & \multicolumn{2}{|c|}{ Turnover ratios (1) } \\
\hline $\begin{array}{c}\text { Lagged returns Granger cause } \\
\text { turnover ratios }\end{array}$ & $0.5937(0.441)$ & $6.7879(0.009)$ \\
\hline \multirow[t]{2}{*}{$\begin{array}{c}\text { Lagged turnover ratios Granger } \\
\text { cause returns }\end{array}$} & $2.4817(0.115)$ & $0.9381(0.333)$ \\
\hline & \multicolumn{2}{|c|}{ Turnover ratios with political events (2) } \\
\hline $\begin{array}{c}\text { Lagged returns Granger cause } \\
\text { turnover ratios }\end{array}$ & $9.1273(0.003)$ & $15.8340(0.000)$ \\
\hline \multirow[t]{2}{*}{$\begin{array}{l}\text { Lagged turnover ratios Granger } \\
\text { cause returns }\end{array}$} & $2.6420(0.104)$ & $0.2735(0.601)$ \\
\hline & \multicolumn{2}{|c|}{ Turnover ratios with macro shocks (3) } \\
\hline $\begin{array}{c}\text { Lagged returns Granger cause } \\
\text { turnover ratios }\end{array}$ & $10.388(0.001)$ & $16.8300(0.000)$ \\
\hline \multirow[t]{2}{*}{$\begin{array}{l}\text { Lagged turnover ratios Granger } \\
\text { cause returns }\end{array}$} & $0.3358(0.562)$ & $0.0068(0.934)$ \\
\hline & \multicolumn{2}{|c|}{ Turnover-volatility ratios (4) } \\
\hline $\begin{array}{l}\text { Lagged returns Granger cause } \\
\text { turnover-volatility ratios }\end{array}$ & $1.3471(0.246)$ & $0.207(0.649)$ \\
\hline \multirow[t]{2}{*}{$\begin{array}{c}\text { Lagged turnover ratios Granger } \\
\text { cause returns }\end{array}$} & $0.1595(0.690)$ & $0.9264(0.336)$ \\
\hline & \multicolumn{2}{|c|}{ Turnover-volatility ratios with political events (5) } \\
\hline $\begin{array}{l}\text { Lagged returns Granger cause } \\
\text { turnover-volatility ratios }\end{array}$ & $0.8498(0.357)$ & $0.1101(0.740)$ \\
\hline \multirow[t]{2}{*}{$\begin{array}{c}\text { Lagged turnover ratios Granger } \\
\text { cause returns }\end{array}$} & $0.0513(0.821)$ & $0.6195(0.431)$ \\
\hline & \multicolumn{2}{|c|}{ Turnover ratios-volatility with macro shocks (6) } \\
\hline $\begin{array}{l}\text { Lagged returns Granger cause } \\
\text { turnover-volatility ratios }\end{array}$ & $0.2091(0.647)$ & $0.5105(0.475)$ \\
\hline $\begin{array}{l}\text { Lagged turnover ratios Granger } \\
\text { cause returns }\end{array}$ & $0.2528(0.615)$ & $0.0148(0.903)$ \\
\hline
\end{tabular}


Table 4: Intervention based model with regulatory changes

$*, * *$, and $* * *$ indicate significance on the 10,5 , and $1 \%$ level of significance.

\begin{tabular}{|c|c|c|c|c|c|c|}
\hline \multirow[t]{2}{*}{ Model type } & \multicolumn{2}{|c|}{ Turnover ratios } & \multicolumn{2}{|c|}{ Turnover-volatility ratios } & \multicolumn{2}{|c|}{$\begin{array}{c}\text { Turnover-volatility ratios } \\
\text { macroeconomic shocks }\end{array}$} \\
\hline & Shanghai & Shenzhen & Shanghai & Shenzhen & Shanghai & Shenzhen \\
\hline$r_{t}$ & $0.0363 * *$ & $0.0437 * * *$ & 0.0016 & $0.0027 * *$ & 0.0016 & 0.0040 \\
\hline $\mathrm{r}_{\mathrm{t}-1}$ & $0.0262 *$ & $0.0374 * * *$ & 0.0000 & $0.0010 *$ & 0.0002 & 0.0014 \\
\hline $\mathrm{T}$ & -0.0083 & -0.0006 & 0.0003 & 0.0005 & 0.0000 & 0.0006 \\
\hline $\mathrm{t} 5$ & 0.4352 & - & -0.0101 & - & - & - \\
\hline $\mathrm{t} 7$ & -0.4815 & - & -0.0112 & - & - & - \\
\hline $\mathrm{t} 18$ & -1.6735 & 0.2557 & -0.107 & $-0.0749 * *$ & -0.1113 & $-0.1376 * * *$ \\
\hline $\mathrm{t} 23$ & $1.9635 *$ & 0.1826 & $0.1335 *$ & 0.0102 & $0.1638 *$ & 0.0041 \\
\hline t33 & 2.9763 & $1.2314 * * *$ & 0.0721 & $0.1048 * * *$ & 0.0686 & $0.0809 * *$ \\
\hline $\mathrm{t} 40$ & $3.0743^{* *}$ & -0.3079 & $0.4913^{* * *}$ & -0.0229 & $0.5070 * * *$ & -0.0170 \\
\hline $\mathrm{t} 43$ & 0.0661 & $-1.3877 * * *$ & -0.0291 & $-0.0606^{*}$ & -0.0363 & $-0.0637 * * *$ \\
\hline $\mathrm{t} 45$ & 2.0888 & -0.3623 & 0.0644 & 0.0870 & 0.0866 & 0.0310 \\
\hline $\mathrm{t} 50$ & -0.3394 & -0.131 & -0.0469 & -0.0105 & -0.0532 & -0.0113 \\
\hline $\mathrm{t} 54$ & $1.0939 * *$ & $1.1221^{* *}$ & $0.0990 *$ & $0.0865 *$ & $0.1321^{* *}$ & 0.0754 \\
\hline $\mathrm{t} 55$ & $-2.1027 * *$ & -0.8064 & $-0.1239 *$ & -0.0676 & $-0.1046^{*}$ & -0.0582 \\
\hline $\mathrm{t} 56$ & -0.5794 & $-1.4421^{* *}$ & -0.0630 & -0.0703 & -0.0565 & -0.0541 \\
\hline $\mathrm{t} 71$ & $2.0106^{*}$ & $1.6753 * * *$ & $0.2008 * * *$ & $0.3535 * * *$ & $0.1863 * * *$ & $0.3319 * * *$ \\
\hline $\mathrm{t} 72$ & 0.9372 & $2.5135 * * *$ & 0.0152 & $0.1158 * * *$ & 0.0081 & $0.0968 * *$ \\
\hline $\mathrm{t} 73$ & $5.9911 * * *$ & $3.8839 * * *$ & $0.4967 * * *$ & $0.2548 * * *$ & $0.4782 * * *$ & $0.2868 * * *$ \\
\hline $\mathrm{t} 78$ & $1.3907 * * *$ & $2.2176 * * *$ & $0.0826^{* *}$ & $0.1097 * * *$ & $0.0820 *$ & $0.1206 * * *$ \\
\hline t79 & 0.2947 & $0.6775 * *$ & 0.0165 & 0.0342 & 0.0235 & 0.0352 \\
\hline t91 & 0.3037 & 0.1138 & 0.0309 & 0.0494 & 0.0333 & 0.0622 \\
\hline $\mathrm{t} 102$ & -0.9463 & -0.3491 & 0.0224 & 0.0066 & 0.0264 & 0.0210 \\
\hline $\mathrm{t} 106$ & 0.0738 & -0.3313 & 0.0348 & -0.0065 & 0.0289 & -0.0050 \\
\hline $\mathrm{t} 111$ & $1.7682 * * *$ & $1.5185 * * *$ & $0.1437 * * *$ & $0.0948 * * *$ & $0.1412^{* * *}$ & $0.0881 * * *$ \\
\hline $\mathrm{t} 122$ & $0.4557 * *$ & 0.1606 & 0.0526 & 0.0345 & 0.0522 & 0.0367 \\
\hline $\mathrm{t} 131$ & 0.3798 & -0.1640 & 0.0048 & -0.0184 & 0.0020 & -0.0191 \\
\hline $\mathrm{t} 132$ & -0.0494 & -0.4480 & -0.0297 & -0.0403 & -0.0307 & -0.0434 \\
\hline $\mathrm{MP}_{\mathrm{t}}$ & - & - & - & - & -0.0045 & 0.0010 \\
\hline $\mathrm{LR}_{\mathrm{t}}$ & - & - & - & - & -0.0025 & 0.0017 \\
\hline $\mathrm{CP}_{\mathrm{t}}$ & - & - & - & - & 0.0413 & $-0.0314 *$ \\
\hline $\mathrm{ER}_{\mathrm{t}}$ & - & - & - & - & 0.7354 & 0.5363 \\
\hline Constant & $2.8648 * * *$ & $1.9380^{*}$ & $0.1541^{* * *}$ & $0.1005 * * *$ & $0.1780 * *$ & $0.0804 * * *$ \\
\hline$\tau_{t-1}$ & 0.3650 & $0.8609 * * *$ & $0.7368^{* *}$ & $0.8178 * * *$ & $0.7492 *$ & $0.8853 * * *$ \\
\hline $\mathrm{u}_{\mathrm{t}-1}$ & 0.7086 & $0.4729 * * *$ & -0.2480 & -0.2627 & -0.3074 & $-0.3568 *$ \\
\hline $\mathrm{u}_{\mathrm{t}-2}$ & 0.4197 & $-0.5271^{* * *}$ & - & - & - & - \\
\hline $\begin{array}{l}\text { Observation } \\
\text { Akaike }\end{array}$ & 131 & 126 & 131 & 126 & 122 & 122 \\
\hline (AIC) & 447 & 323 & -210 & -320 & -180 & -320 \\
\hline $\begin{array}{l}\text { Schwarz } \\
\text { (SIC) }\end{array}$ & 539 & 405 & -120 & -240 & -92 & -220 \\
\hline
\end{tabular}


Fig. 1. Development of float share value in billion Yuan relative to total share value

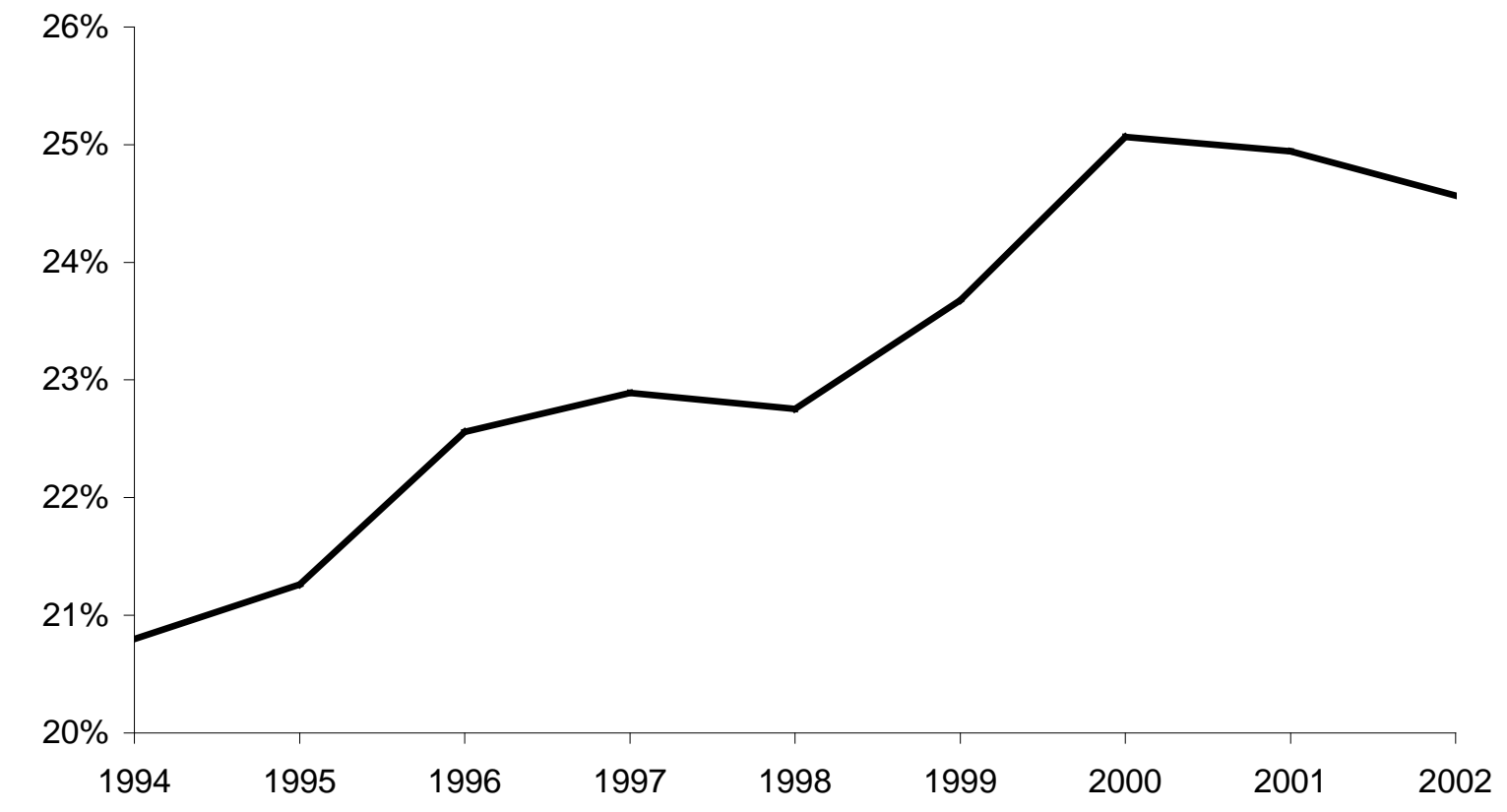

Source: China Securities and Futures Market Statistical Data, 2002 
Fig. 2. Development of turnover ratios and turnover-volatility ratios
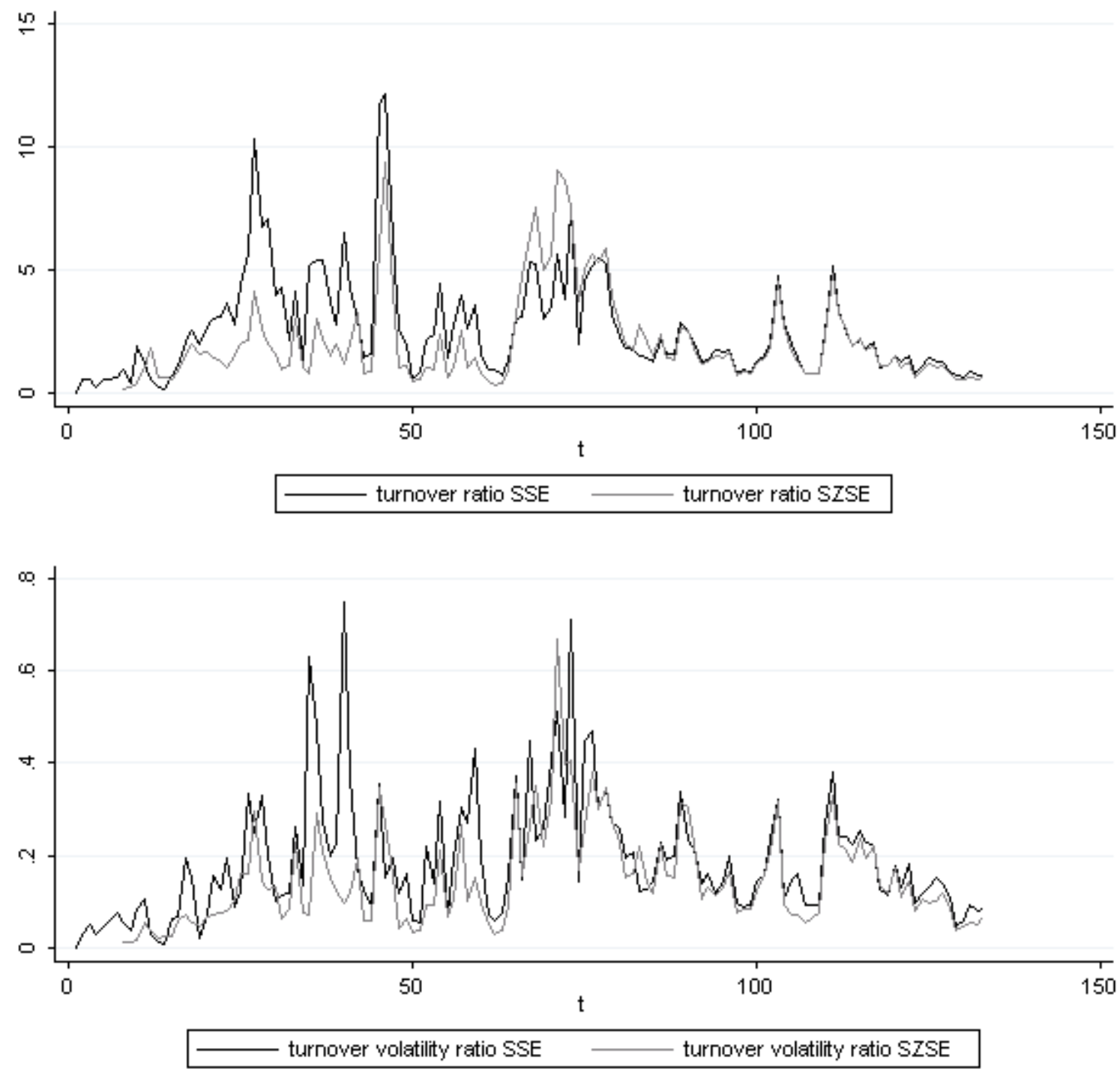
Fig. 3. The dynamic responses of turnover ratios caused by market reforms

This figure illustrates significant policy changes and the dynamic response in market liquidity triggered by these regulatory changes. Coefficients that are significant on the $95 \%$ level of confidence represent the immediate response of market liquidity. Due to the autoregressive nature of turnover ratios, reactions die out quickly.

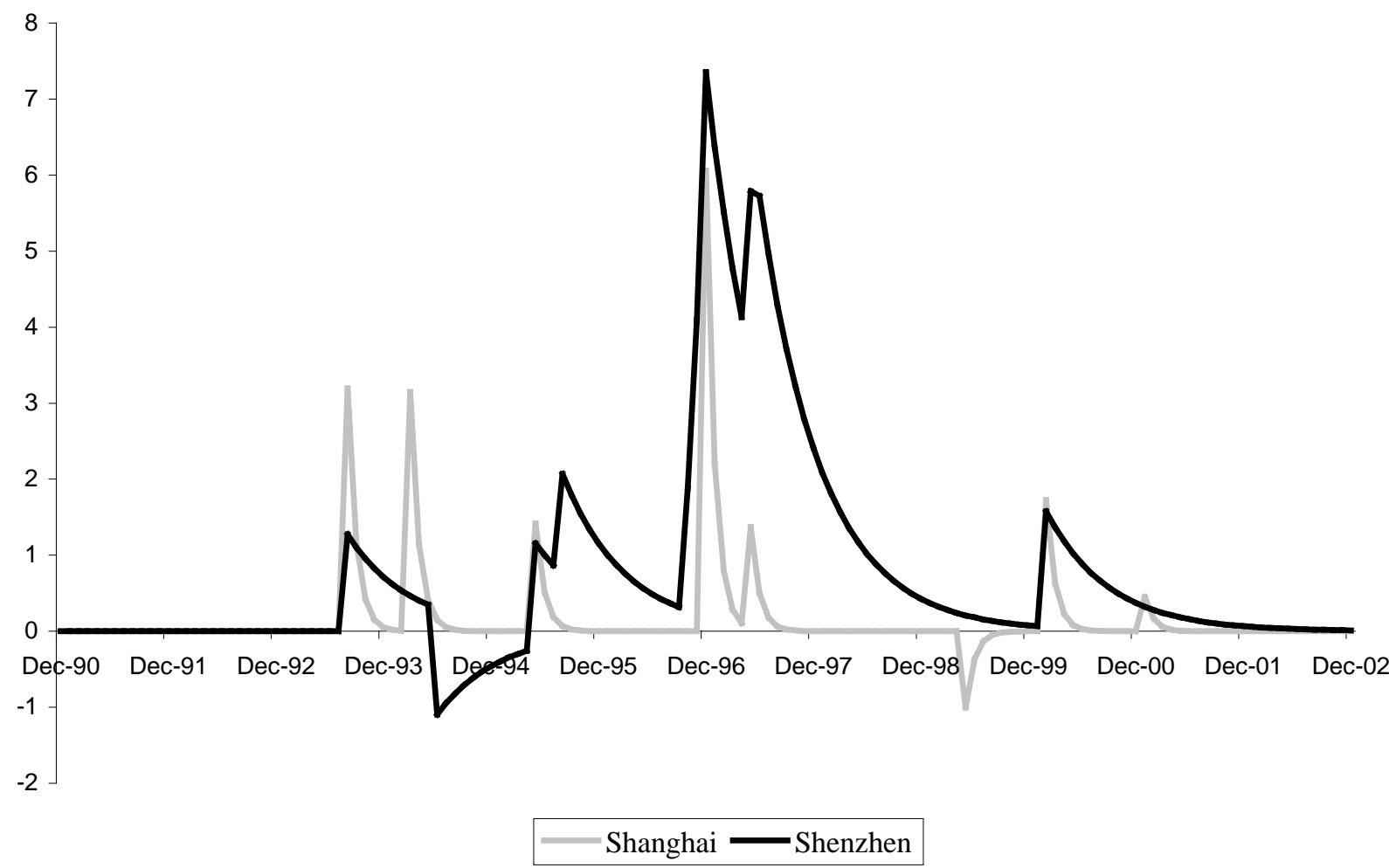

